\title{
MOLECULAR MARKERS OF MUCOSA HARBORING GASTRIC ADENOMAS
}

\author{
Adriana Vaz SAFATLE-RIBEIRO', Kátia Adriana Tessima FRANCO'1, \\ Carlos Eduardo Pereira CORBETT ${ }^{2}$, Kiyoshi IRIYA², \\ Bruno ZILBERSTEIN ${ }^{1}$ and Ulysses RIBEIRO Jr. ${ }^{1}$
}

\begin{abstract}
Context - Gastric adenoma is a precursor lesion of the adenocarcinoma. Objective - To characterize gastric adenomas according to the mucin immunoexpression and to evaluate the immunoexpression of p53, p16 ${ }^{\text {ink4a }}, \mathrm{BCL}-2$, cyclin D, Ki-67, in the adenoma and in the gastric mucosa harboring adenoma. Methods - Forty gastric specimens from 20 patients were classified as intestinal (MUC2 - goblet cell mucin) or foveolar (MUC5AC - gastric-foveolar mucin) adenomas. Immunohistochemistry was performed using streptavidin-biotin-complex method. Results - Twelve $(60 \%)$ patients were men. The mean age was $67.9 \pm 12.9$ years-old. Intestinal adenomas were detected in $13(65 \%)$ patients and gastric type in $7(35 \%)$. Low-grade dysplasia was present in $13(65 \%)$ of the adenomas, high-grade in $3(15 \%)$, and adenocarcinoma within the polyp in $4(20 \%)$. Six $(30 \%)$ patients had synchronous adenocarcinoma. p53 immunoexpression was observed in 6/20 (30\%) of adenomas, and in 2/6 (33.3\%) of synchronous tumors. There was an association between 553 immunoexpression and intestinal type of adenoma/tumor, $P=0.04$. There was no association between p16 ${ }^{\text {inkaa }}$, Bcl-2, cyclin D and Ki-67 and adenoma clinicopathological characteristics. Conclusion - Immunohistochemistry may be useful to classify the adenomas subtypes and may define the pathway of adenoma to carcinoma sequence.
\end{abstract}

KEYWORDS - Stomach neoplasms. Adenocarcinoma. Tumor markers, biological. Gene expression regulation, neoplastic. Immunohistochemistry.

\section{INTRODUCTION}

Gastric adenoma is considered a precursor lesion for the development of adenocarcinoma in the stomach $^{(1,24)}$. It is defined as raised lesion of dysplasic epithelium and can be present as plain, villous, pedun-

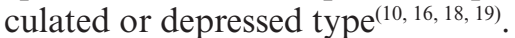

The adenomas can contain focus of intestinal differentiation, with goblet cells and/or Paneth cells (intestinal type), or only dysplasic foveolar epithelium (gastric type). It has been demonstrated that almost all adenomas of the intestinal type grow in a mucosa with metaplasia and gastric atrophy, and about $40 \%$ have high grade dysplasia. In contrast, adenomas of the foveolar type tend to develop in apparently normal epithelium, in a non atrophic mucosa and rarely present high degree of dysplasia or synchronous adenocarcinoma ${ }^{(2)}$.

Immunohistochemical staining for mucins may be useful to differentiate adenomas of gastric or foveolar phenotype, which are derived from the foveolar gastric epithelium of those of intestinal phenotype, which are derived from the metaplastic epithelium ${ }^{(5,22)}$. Additionally, gastric carcinomas immunoexpressing mucins of the foveolar type are associated with worst prognosis and greater malignant potential, when compared to those with mucins of the intestinal type ${ }^{(22,23)}$.

The adenoma subtype characterization is relevant because it may guide the treatment management (endoscopic intervention or surgical resections). Moreover, the routes of carcinogenesis of the gastric adenomas are controversial and the profile of genetic alteration is not completely known.

Thus, the aim of this investigation was to classify the adenomas according to the mucin immunoexpression: MUC2 (mucin of the goblet cell) and MUC5AC (mucin of the gastric cell or foveolar); and to associate the phenotypic pattern of the adenomas with the immunoexpression of p53 (tumor suppressor gene), p16 ${ }^{\text {INK4a }}$ (tumor suppressor gene), Bcl-2 (Proto-oncogene - apoptosis), cyclin D (cell cycle) and Ki-67 (MIB-1) (cellular proliferation) in the adenomas and in the mucosa harboring them.

\section{METHODS}

Forty specimens from 20 patients who underwent gastric resection or endoscopic mucosal resection

Declared conflict of interest of all authors: none

Departamento de Gastroenterologia: 2 Departamento de Patologia Faculdade de Medicina da Universidade de São Paulo, São Paulo, SP Brasil.

Correspondence: Prof. Adriana Vaz Safatle-Ribeiro - Rua Treze de Maio, 1954 - Cj. 54 - Bela Vista - 01327-002 - São Paulo, SP, Brazil - E-mail: adrisafatleribeiro@terra.com.br 
for gastric adenoma were analyzed. The biological material and clinical data were obtained at the Endoscopy Unit and Gastrointestinal Surgery Division, of the Department of Gastroenterology, University of São Paulo Medical School and the immunohistochemical analysis was carried out at the Pathology Department of the same University. This study was approved by the institutional review board of the Hospital das Clínicas of the University of São Paulo Medical School. Formalin fixed specimens were $4 \mathrm{~mm}$ sectioned, and the morphologic data was defined through $\mathrm{H}$-E staining. Adjacent mucosa, with at least $3 \mathrm{~cm}$ of distance from the adenoma, were collected for comparative purposes.

\section{Immunohistochemistry}

The immunohistochemical method used was the streptavidin-biotin-peroxidade complex method. Molecular markers evaluated were: MUC2 clone Ccp58 (dilution 1:100), MUC5AC clone CLH2 (dilution 1:400), p53 clone DO7 (dilution 1:100), p16 $6^{\mathrm{INK} 4 \mathrm{a}}$ clone 16P04 (dilution 1:200), Bcl-2 clone MO887 (dilution 1:80), cyclin D clone DCS-6 (dilution 1:200), and Ki-67 clone MIB-1 (dilution 1:50).

All the sections were heated in a $10 \mathrm{mM}$ citrate buffer $\mathrm{pH}$ 6.0, except MUC5AC. Immunoreactions were visualized with diaminobenzidine $(\mathrm{DAB})^{(20)}$.

Histologic sections of stomach and colon adenocarcinoma, previously known for expressing high levels of $\mathrm{p} 53$, p16 $6^{\mathrm{INK} 4 \mathrm{a}}$, Bcl-2, cyclin D and Ki-67, mucins MUC2 and MUC5AC, were used as positive controls.

The negative controls corresponded to the same histological sections of colonic and gastric adenocarcinoma with the omission of the primary antibody. Nuclear (p53, p16 INK4a $^{\mathrm{IN}}$ and cytoplasmic immunoreactivity (p16 $6^{\mathrm{INK} 4 \mathrm{a}}$, Bcl-2, cyclin D and mucins), were classified quantitatively, in a scale of 0 the 4, for the intensity and distribution (intensity: $0=$ absence staining; $1=$ hardly visible staining; 2 = easily visible, however weak; 3 = intense, however not as much as the control; $4=$ so intense as the control; distribution: $0=$ absence of coloration or $75 \%)^{(6,7,20)}$.

p53 immunoexpression was considered positive with intensity above 3 and distribution 3 or 4 ; for $\mathrm{p} 16^{\mathrm{INK} 4 \mathrm{a}}$ some authors consider cytoplasmic positivity for $\mathrm{p} 16^{\mathrm{INK} 4 \mathrm{a}}$ and others, the nuclear one. In this research, p16 $6^{\mathrm{INK} 4 \mathrm{a}}$, was considered positive if intensity and distribution were graduated as 2, 3 or 4. For Bcl-2 and Cyclin D, both are cytoplasmic stainings, and were considered positive if 3 or 4 for intensity and distribution ${ }^{(6,7,18,29)}$.

For Ki-67, the cells were characterized as positive even if stained weakly. The Ki-67 index was calculated as the percentage of positive cells (counting the cells with positive nuclei and dividing themselves for the total number of cells). A minimum of 1,000 cells were counted, in the hot spot areas, using 400X magnification of an optic microscope. The Ki-67 marker was classified as high index of cellular proliferation when the positivity was greater than $25 \%$ of the cells and low index when the cellular distribution was lesser than $25 \%$ of the positive cells. This was based on the normal stomach immunoreactivity for $\mathrm{Ki}-67^{(18)}$.

\section{Statistical analysis}

Student $t$ test was utilized to compare the quantitative data, and Fisher's exact test was calculated to analyze qualitative data. Both tests were considered significant when the $P$ value was less than $<0.05$. The statistical program used was SPSS for Windows, version 18.0 (SPSS Incorporation Philadelphia, Pennsylvania, USA).

\section{RESULTS}

The clinical pathological characteristics of the 20 adenoma patients are presented in Table 1 .

TABLE 1. Clinical-pathological comparisons between intestinal and foveolar adenomas according to mucin immunoexpression

\begin{tabular}{|c|c|c|c|c|}
\hline & & $\begin{array}{l}\text { Intestinal } \\
\text { (MUC-2) }\end{array}$ & $\begin{array}{l}\text { Foveolar } \\
\text { (MUC5AC) }\end{array}$ & $P$ value \\
\hline Mean Age & & $67.1 \pm 8.7$ & $69.4 \pm 9.6$ & $0.71^{\wedge}$ \\
\hline \multirow{2}{*}{ Gender } & Male & 8 & 4 & $0.97 *$ \\
\hline & Female & 5 & 3 & \\
\hline \multirow{2}{*}{ Size } & $<2 \mathrm{~cm}$ & 11 & 0 & $0.0004^{*}$ \\
\hline & $>2 \mathrm{~cm}$ & 2 & 7 & \\
\hline \multirow{2}{*}{$\begin{array}{l}\text { Adenoma } \\
\text { location }\end{array}$} & Proximal & 4 & 4 & $0.35 *$ \\
\hline & Distal & 9 & 3 & \\
\hline \multirow{2}{*}{$\begin{array}{l}\text { Growth } \\
\text { pattern }\end{array}$} & Flat & 5 & 2 & $0.62 *$ \\
\hline & Polypoid & 5 & 5 & \\
\hline \multirow{3}{*}{$\begin{array}{l}\text { Viena's } \\
\text { Classification }\end{array}$} & III & 10 & 3 & $0.007 *$ \\
\hline & IV.1 & 3 & 0 & \\
\hline & IV. 4 & 0 & 4 & \\
\hline \multirow{3}{*}{$\begin{array}{l}\text { Cancer } \\
\text { Association }\end{array}$} & Synchronic & 4 & 2 & $0.006 *$ \\
\hline & $\begin{array}{l}\text { In the } \\
\text { adenoma }\end{array}$ & 0 & 4 & \\
\hline & Absent & 9 & 1 & \\
\hline \multirow{2}{*}{$\begin{array}{l}\text { p53- } \\
\text { adenomas }\end{array}$} & Negative & 7 & 7 & $0.04 *$ \\
\hline & Positive & 6 & 0 & \\
\hline \multirow{2}{*}{$\begin{array}{l}\text { p16 }{ }^{\mathrm{INK} 4 a} \\
\text { cytoplasmic }\end{array}$} & Negative & 5 & 2 & $0.97 *$ \\
\hline & Positive & 8 & 5 & \\
\hline \multirow{2}{*}{$\begin{array}{l}\text { p16 }{ }^{\text {INK4a }} \\
\text { nuclear }\end{array}$} & Negative & 4 & 2 & $0.98 *$ \\
\hline & Positive & 9 & 5 & \\
\hline \multirow{2}{*}{ Cyclin D } & Negative & 3 & 1 & $0.98 *$ \\
\hline & Positive & 10 & 6 & \\
\hline \multirow{2}{*}{$\mathrm{Bcl}-2$} & Negative & 2 & 1 & $0.99 *$ \\
\hline & Positive & 11 & 6 & \\
\hline \multirow{2}{*}{$\mathrm{Ki}-67$} & $<25 \%$ & 3 & 3 & $0.61 *$ \\
\hline & $>25 \%$ & 10 & 4 & \\
\hline
\end{tabular}

$\wedge=$ Student $t$ test; $*$ Fisher exact test 
Twelve $(60 \%)$ patients were men. The mean age was 67.9 years-old, varying from 43 and 84 years-old.

As a result of mucin immunoexpression (MUC2 and MUC5AC), the adenomas were classified as: $13(65 \%)$ of intestinal type and $7(35 \%)$ of the gastric type (Figures 1 and 2).

In relationship to the gastric adenoma location, seven cases were located at the body, one at the cardia and 12 at the antrum.

The size of the lesions varied from $0.8 \mathrm{~cm}$ to $6 \mathrm{~cm}$ in diameter. Nine lesions were larger than $2 \mathrm{~cm}$ and 11 lesions equal or smaller than $2 \mathrm{~cm}$ in diameter. The phenotype distribution according to the size of the adenoma demonstrated that $11 / 13(65 \%)$ lesions of the intestinal type were smaller than $2 \mathrm{~cm}$, while $2 / 13$ were larger than $2 \mathrm{~cm} ; 7 / 7(100 \%)$ of the gastric type were larger than $2 \mathrm{~cm}, P=0.0004$. (Table 1) There was no association between lesion location and phenotype of the adenomas.

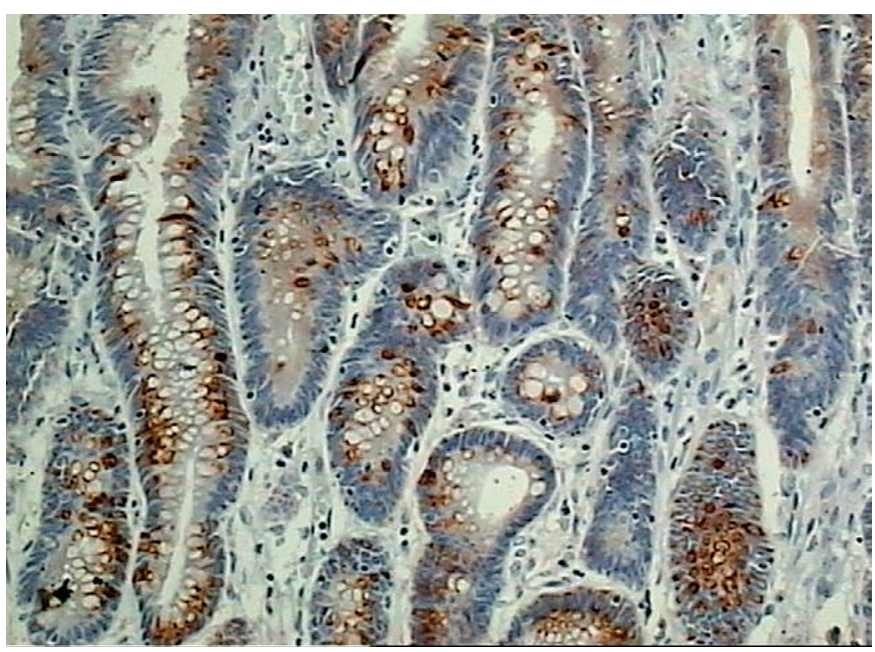

FIGURE 1. Intestinal type adenoma with mucin immunoexpression for MUC2 (x20)

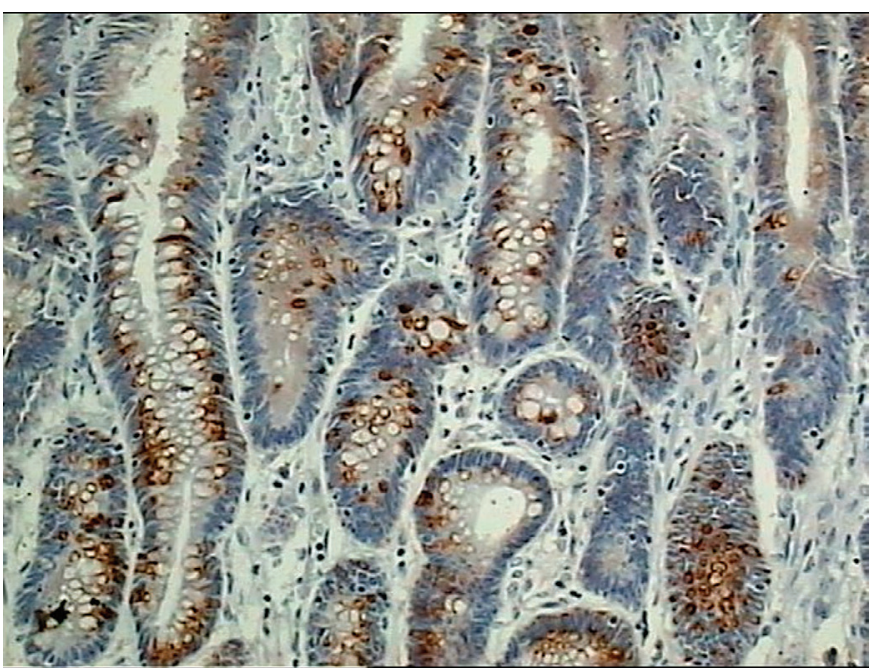

FIGURE 2. Gastric type adenoma with immunoreactivity for MUC5AC $(\mathrm{x} 40)$
The endoscopic findings were: six slightly elevated lesions, seven sessile and four elevated with central depression (Table 1). Such finding did not associate with mucin phenotype.

Accordingly to the modified Vienna's Classification, the intestinal type adenomas were classified as: 10/13 low grade (grade III.1 of Vienna) and 3/13 high grade (grade IV.1 of Vienna); and the gastric type adenomas, 3/7 were classified as low grade (grade III.1 of Vienna) and 4/7 were classified as intramucous carcinoma (grade IV.4 of Vienna) (Table 1).

Gastric adenocarcinoma were detected concurrently in $10 / 20(50 \%)$ of the gastric adenomas cases. Of the 10 cases with cancer, 6 presented synchronous adenocarcinoma, corresponding to $30 \%(6 / 20)$ and 4 presented adenocarcinoma in the adenoma, corresponding to 20\% (4/20) (Table 1).

In relationship to the adenomas with synchronous lesions, the mucin immunoexpression (MUC2 and MUC5AC) demonstrated that in six adenomas cases with synchronous adenocarcinoma, two $(33.3 \%)$ cases were classified as gastric type and four $(66.7 \%)$ as intestinal type (Table 1$)$.

All the patients had intestinal metaplasia and atrophy in the adjacent mucosa, independently of the histological type of the adenoma.

p53 adenoma immunoexpression is presented in Table 1 . Of the 20 adenomas, 6 presented positivity for $\mathrm{p} 53$ and all of them were intestinal type. While all positive p53 adenomas were classified as intestinal type, none adenoma of the gastric type were p53 positive. This difference was statistically significant $(P=0.04)$. Two/six $(33 \%)$ positive synchronous adenocarcinoma for $\mathrm{p} 53$ were also of the intestinal type. On the other hand, p53 was negative in all four cases with focus of adenocarcinoma in the adenoma (Figures $3 \mathrm{~A}$ and $3 \mathrm{~B}$ ).

Thirteen adenomas were positive for $\mathrm{p} 16^{\mathrm{INK} 4 \mathrm{a}}$ considering the cytoplasm reactivity, and seven cases were negative. Considering the nuclear positivity, 14 cases of adenomas were positive and 6 cases were negative for the $\mathrm{p} 16^{\mathrm{INK} 4 \mathrm{a}}$ (Table 1$)$.

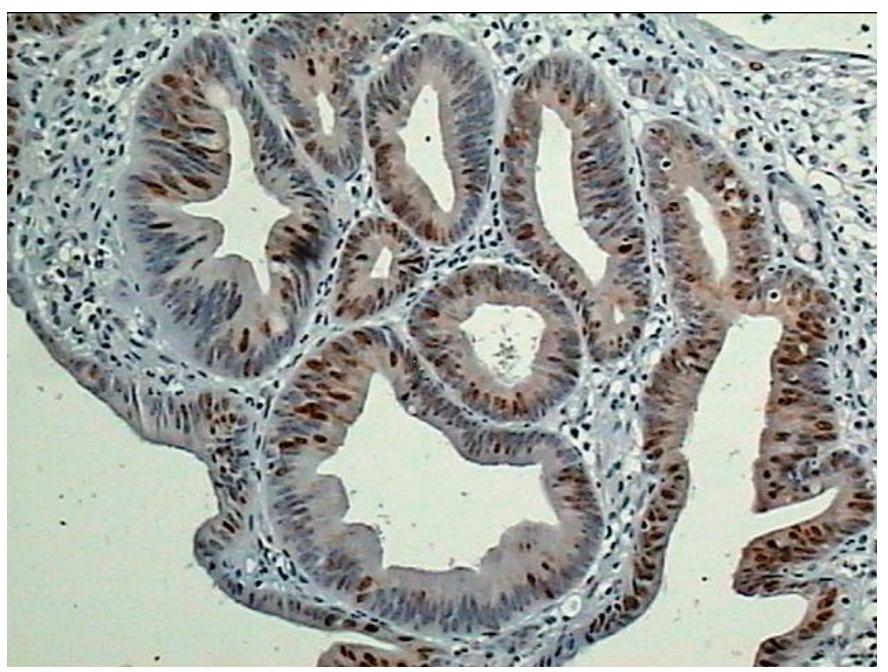

FIGURE 3A. p53 nuclear immunoexpression in the adenoma is presented (x20) 


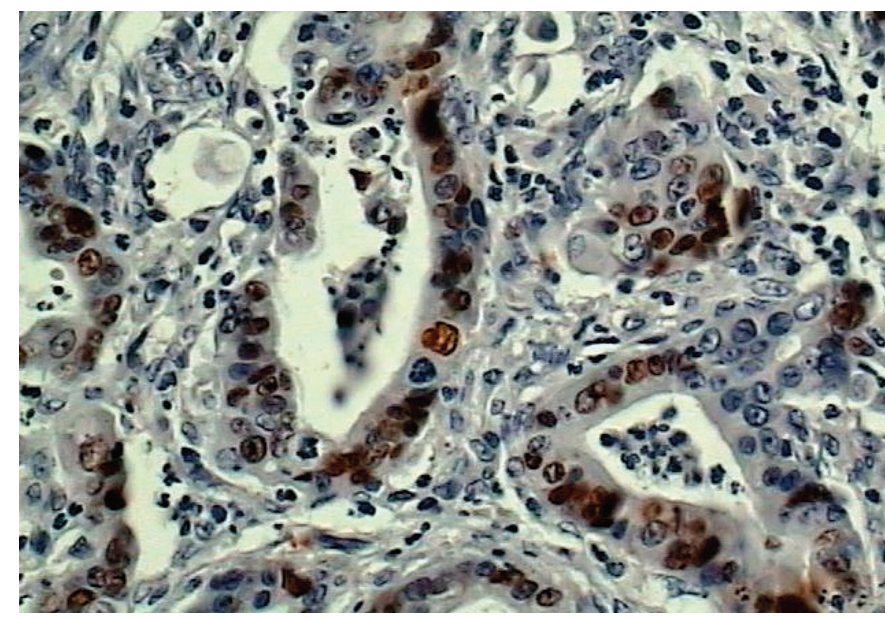

FIGURE 3B. p53 immunoreactivity in adenocarcinoma can be seen (x 40)

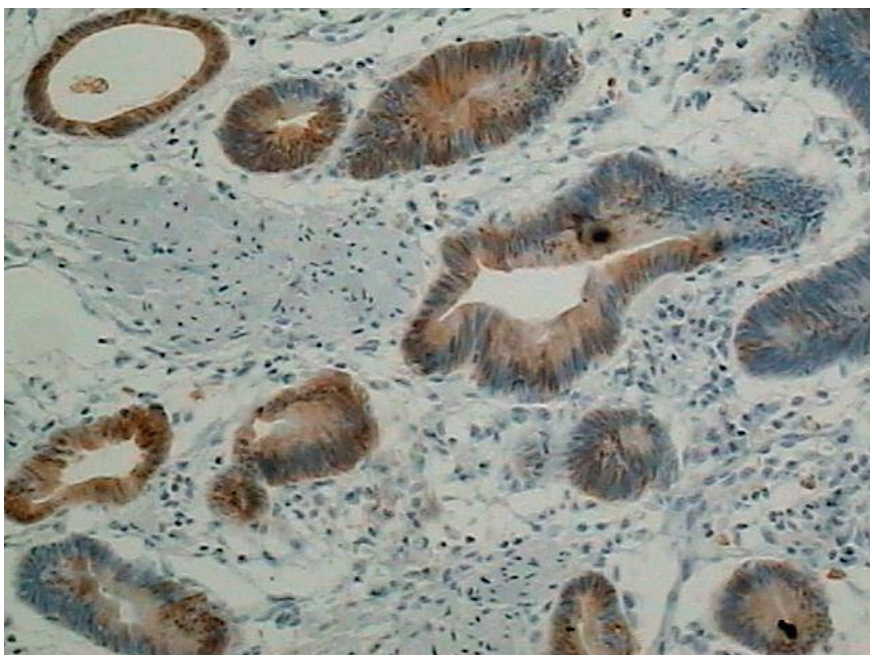

FIGURE 4A. Cytoplasmic immunoexpression for $\mathrm{p} 16^{\mathrm{INK} 4 \mathrm{a}}$ in the adenoma $(x 20)$

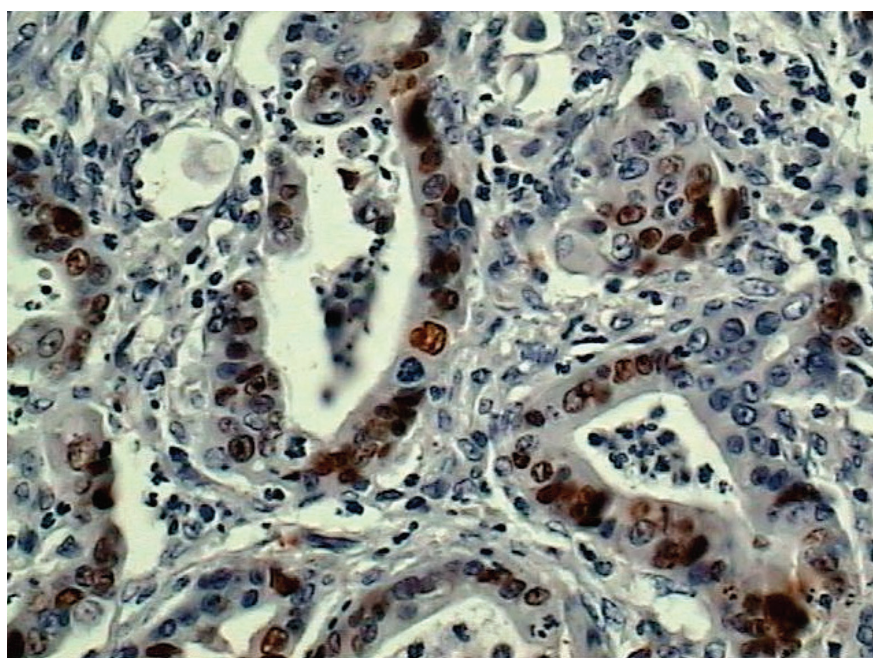

FIGURE 4B. Nuclear and cytoplasmic staining for $\mathrm{p} 16^{\mathrm{INK} 4 \mathrm{a}}$ in the adenoma (x20)
Of the six analyzed cases of synchronous adenocarcinoma, four were positive for $\mathrm{p} 16^{\mathrm{INK} 4 \mathrm{a}}$ and two were negative, considering both cytoplasmic and nuclear staining (Figures 4A and $4 \mathrm{~B})$.

Cyclin D immunoexpression was positive in 16/20 (80\%) of the adenomas. In relationship to the cases of synchronous adenocarcinoma, $3 / 6(50 \%)$ were positive for cyclin D (Figure 5).

Bcl-2 imunoexpression was noted in 17/20 (85\%) cases of analyzed adenomas (Table 1). In the synchronous adenocarcinomas, four/six cases were positive for the Bcl-2 (Figure 6).

In the adenomas, $14 / 20(70 \%)$ presented high index of cellular proliferation (higher than $25 \%$ of the cells) and $6 / 20$ $(30 \%)$ presented low index (lesser than $25 \%$ ) (Table 1). There was no association between cellular proliferation and phenotype of adenoma or adenocarcinoma. High index of cellular proliferation was observed in $5 / 6(83 \%)$ cases of synchronous

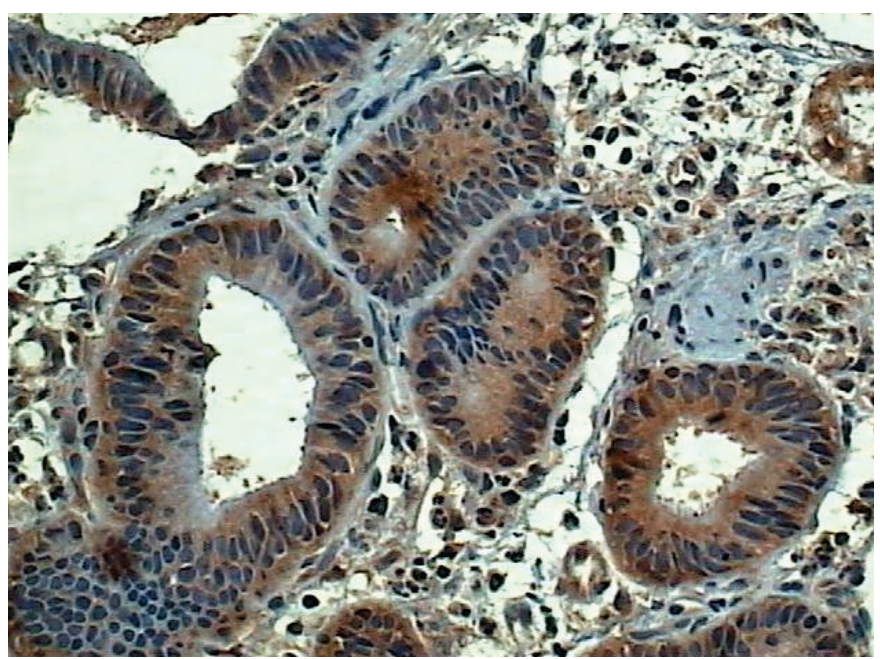

FIGURE 5. Cyclin D cytoplasmic immunoexpression was positive in the majority of the adenomas $(\mathrm{x} 40)$

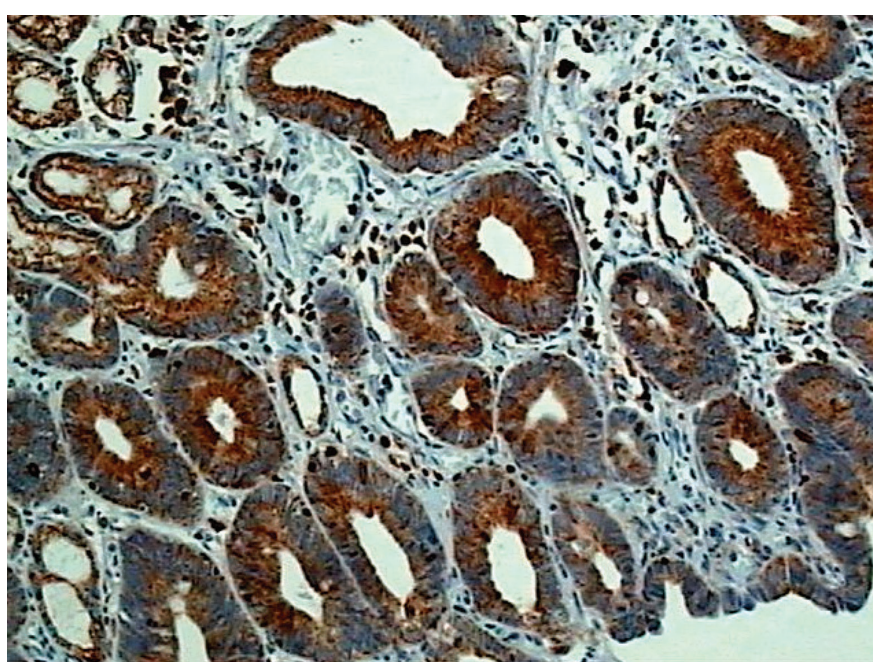

FIGURE 6. Bcl-2 cytoplasmic imunoexpression in the adenoma is noted (x20) 
adenocarcinoma. In the synchronous adenocarcinoma, the cellular proliferation labeled index was higher than in the adenomas, $P=0.049$. Figures $7 \mathrm{~A}$ and $7 \mathrm{~B}$ represent the result of immunohistochemistry for Ki-67 in the adenoma and adenocarcinoma, respectively (Figures 7A and 7B).

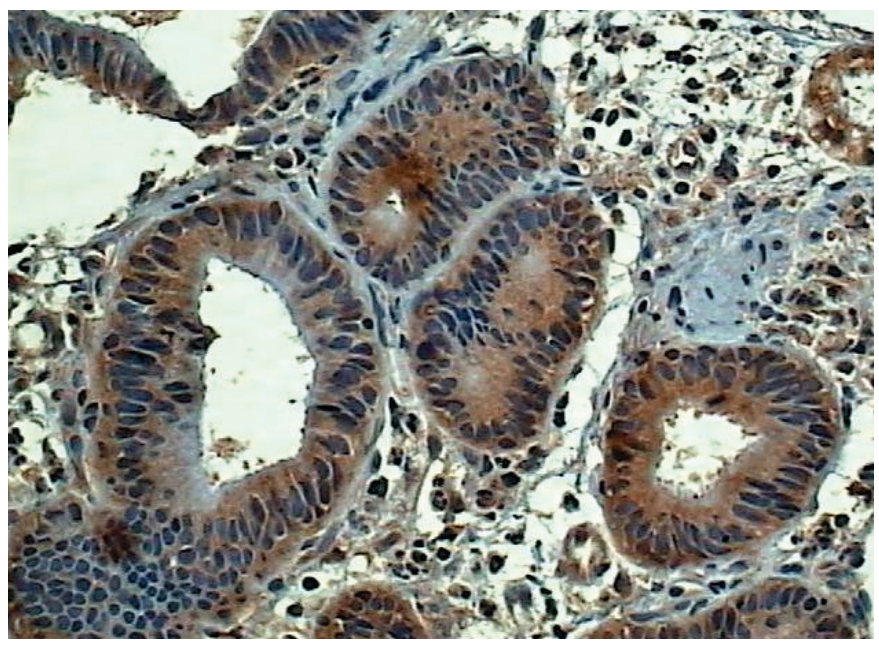

FIGURE 7A. Immunohistochemistry for Ki-67 in the adenoma (x10)

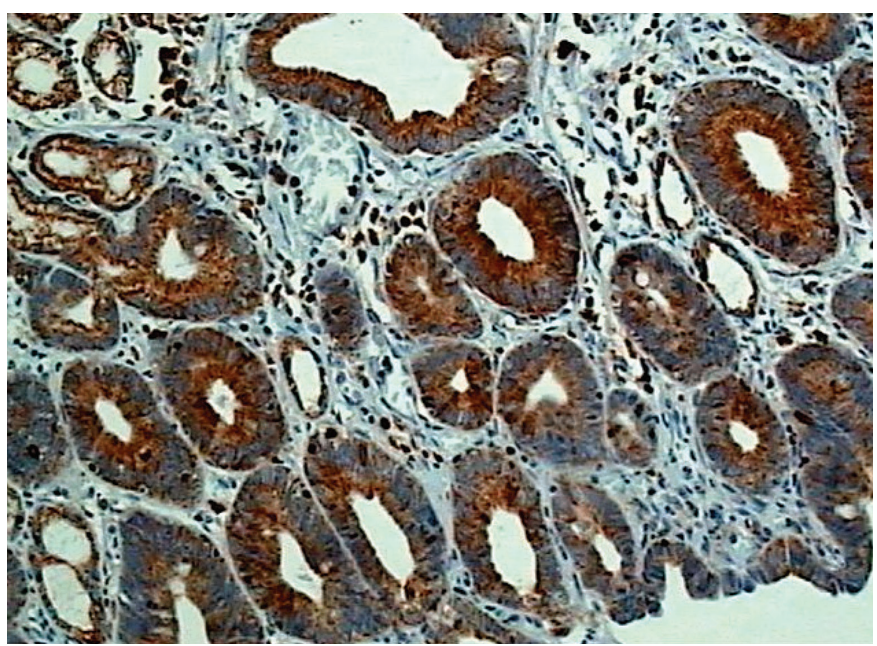

FIGURE 7B. Immunohistochemistry for Ki-67 in the adenocarcinoma (x20)

\section{DISCUSSION}

The incidence of gastric adenoma is low, varying from $0.1 \%$ to $2 \%$ of the patients ${ }^{(10)}$; however, the frequency of its malignant transformation is elevated, varying from $3.5 \%$ to $40 \%{ }^{(4)}$. Nonetheless, numerous studies reported the association between gastric adenoma and carcinoma. The incidence of malignancy is dependent on the size of the adenoma. Adenomas smaller than $20 \mathrm{~mm}$ of diameter have 2\%-10\% of chance to harbor malignancy, while in those larger than $20 \mathrm{~mm}$, these numbers go up to $40 \%-50 \%$. Foci of adenocarcinoma were diagnosed in more than $80 \%$ of the adenomas larger than $4 \mathrm{~cm}^{(25)}$.
Recently, the mucins have been utilized as a new diagnostic modality to explore the biological mechanism in the growth cellular lines and tumoral differentiation ${ }^{(19,22)}$.

MUC 2 is a glycoprotein that is present in epithelial tissue, and its is associated with intestinal phenotype, being observed in the small intestine and colon and in the goblet cells of the intestinal metaplasia. It is not detected in normal gastric mucosa ${ }^{(13,15,19,23,26)}$.

MUC5AC is expressed in the surface of normal gastric mucosa cells, in the foveolar epithelium of the body and antrum. Its expression is associated to the gastric phenotype and is generally observed in gastric carcinomas of the diffuse type $\mathrm{e}^{(13,15,26)}$.

In the present study, according to the mucin immunoexpression, there was a predominance of the intestinal type adenoma $13 / 20$, and most of them were classified as type III according to modified Vienna's Classification (10/13), while most of the foveolar type adenoma were classified as type IV.4 (4/7). This data may indicate a more aggressive behavior for the foveolar type adenoma. Some authors also have reported higher frequency of intestinal type gastric adenomas based on the mucin immunoexpressions. These authors suggested that the tumoral tissue is a reflex of the phenotype of the adjacent mucosa. They concluded that the depressed adenoma and its adjacent mucosa with incomplete intestinal type phenotype presents neoplastic potential and must be followed carefully ${ }^{(2,19)}$.

The clinical and pathological findings of the gastric adenomas are still not completed understood. In the present study, the five studied immunohistochemical markers were utilized to evaluate: proliferation and cellular control, Ki-67; gene Bcl-2 that participates of the programmed death cellular (apoptosis), tumor suppressor genes $\mathrm{p} 53$ and $\mathrm{p} 16^{\mathrm{INK} 4 \mathrm{a}}$, and gene that regulates the cellular cycle, as cyclin D.

The tumor suppressor gene $\mathrm{p} 53$ is located in the chromosome $17 \mathrm{p}$, codifies a nuclear protein of $53 \mathrm{kD}$ and is often involved in human carcinogenesis ${ }^{(8,20)}$. It participates on the regulation of the cellular cycle, causing an inhibitory effect in the proliferation and transformation, causing the cell to rest in the G1 phase of the cellular cycle ${ }^{(14)}$. It is also responsible for the synthesis and repair of the DNA, being considered as the "genoma guardian". The loss of the function of p53 can result in defect in the replication of the DNA and malignant transformation $^{(17)}$ with increase of the genomic instability, changes in ploydia and survival of the cells with increase number of mutations ${ }^{(14)}$.

p53 alteration has been demonstrated in up to $37.5 \%$ of the cases with intestinal metaplasia, from $30 \%$ to $60 \%$ in gastric adenomas or dysplasia and from $43 \%$ to $70 \%$ gastric carcinomas, indicating that p53 participates of the initial phases of gastric carcinogenesis ${ }^{(20,24)}$.

In the present immunohistochemical study, $\mathrm{p} 53$ positivity in adenoma was demonstrated in 6/13 cases of intestinal type, while p53 was negative in all foveolar adenoma phenotype cases. Similarly, in synchronous adenocarcinoma, two/six positive cases for p53 also presented intestinal phenotype. Likewise, Sakurai et al. ${ }^{(21)}$ found p53 positivity in 12 of 32 
adenomas $(38 \%)$. Oya et al ${ }^{(6)}$ also studied 50 cases of adenoma, correlating phenotype with the expression of $\mathrm{p} 53$. p53 immunoexpression was positive in the intestinal type adenomas and the indeterminate type, not being positive in the foveolar adenomas. Such finding strengthens the idea of distinct routes of carcinogenesis, one involving alterations of the p53 tumor suppressor gene as a foremost alteration.

The p16 $6^{\mathrm{INK} 4 \mathrm{a}}$ gene is located in the chromosome $9 \mathrm{p} 21$ and is involved with the regulation of the cellular cycle ${ }^{(28)}$. The $\mathrm{p} 16^{\text {INK4a }}$ gene is inactivated by mutations, homozigotics deletions, or metilation in diverse tumors of different origins and these metilation can result in deregulation of the cellular cycle ${ }^{(29)}$.

In the present study, $\mathrm{p} 16^{\mathrm{INK} 4 \mathrm{a}}$ cytoplasmic positivity was similar to the nuclear staining. In the synchronous adenocarcinomas, cytoplasmic and nuclear staining were observed in four/six cases, however there was no association with clinical and pathological data.

Bcl-2 altered immunoexpression has been detected in gastric premalignant lesions ${ }^{(6)}$. In this study, it was demonstrated high percentage of Bcl-2 positivity in the adenomas, (17/20 positives) and in adenocarcinomas (4/6 positives). However, there was no association of these findings with clinical and pathological characteristics of the lesions. Other authors have found decreased immunoexpression in the adenocarcinomas associated to the adenomas ${ }^{(27)}$.

The cyclin $\mathrm{D}$ gene, which is identified in prad-1 oncogene, codifies a protein that regulates the cellular cycle and is expressed in high levels during the G1 phase of the cellular cycle $^{(18,24)}$. Although highly frequent, there was no association between Cyclin D immunoexpression in the adenomas or tumors, and clinicopathological characteristics.

Ki-67 antibody detects a nuclear protein of 345 to $395 \mathrm{kD}$, codified by a gene in the chromosome 10 , which is present in G1, S, G2 and M phases of the cellular cycle, however absent in the cells in rest or G0 29. Cattoretti et al. ${ }^{(3)}$ produced MIB-1 monoclonal antibody, characterized as equivalent to the $\mathrm{Ki}-67$, presenting the great advantage to be used in paraffin-embedded tissue blocks.

There was no difference in proliferation between the foveolar or intestinal phenotype, indicating that cell pro- liferation is deregulated in both adenoma types, despite of mucin phenotype.

Immunohistochemical analysis can, therefore, be useful to better understand the clinical and pathological characteristics of the adenomas (intra-epithelial neoplasia). In the patients with intestinal type adenoma, in different locations of the stomach, a careful endoscopic investigation should be carried out, with multiple biopsies, since all the mucosa can be altered with the presence of intestinal metaplasia and atrophy and, consequently, with higher possibility of an association with another focus of adenocarcinoma. On the other side, adenomas of the foveolar type seem to be more aggressive lesions, with large size, and may require more extended local resection (endoscopic or surgical) to avoid local recurrence ${ }^{(16,25)}$.

\section{CONCLUSION}

According to the present study, it can be concluded that the mucin phenotype may be used to differentiate gastric adenomas (foveolar and intestinal type). There was a higher labeled index of proliferation (Ki-67) in carcinomas compared to adenomas, however, both adenoma types were highly proliferative compared to the normal mucosa. p53 overexpression was associated to the intestinal type adenoma and synchronous adenocarcinoma, indicating the same route of carcinogenesis. On the other hand, there was no association between the molecular markers $\mathrm{p} 16^{\mathrm{INK} 4 \mathrm{a}}$, cyclin $\mathrm{D}, \mathrm{Bcl}-2$ and the clinical and pathological characteristics of the mucosa harboring the adenomas. Therefore, immunohistochemistry panel of markers may be utilized to better understand the clinicopathological characteristics of the adenoma in the setting of mucosal damage and probably might be used to guide the appropriate treatment.

\section{ACKNOWLEDGEMENTS}

We are grateful to Thaíse Yumie Tomokane for performing immunohistochemistry, and to Michele Tatiana Pereira Tomitão and Evelise Pelegrinelli Zaidan for providing assistance in this manuscript submission.

Safatle-Ribeiro AV, Franco KAT, Corbett CEP, Iriya K, Zilberstein B, Ribeiro Jr. U. Marcadores moleculares em adenomas gástricos. Arq Gastroenterol 2013,50(2):141-7.

RESUMO - Contexto - Adenoma gástrico é uma lesão precursora do adenocarcinoma. Objetivo - Melhor caracterizar os adenomas de acordo com a imunoexpressão de mucinas e avaliar a imunoexpressão de p53, p16 ${ }^{\text {ink4a }}$, BCL-2, cyclin D, Ki-67, nos adenomas e na mucosa gástrica adjacente. Métodos - Quarenta espécimes gástricos provenientes de 20 pacientes portadores de adenomas foram classificados como do tipo intestinal (MUC2 - mucina presente nas células caliciformes) ou gástrico (MUC5AC - mucinas de padrão foveolar). Realizou-se imunoistoquímica para p53, p16 ${ }^{\text {ink4a }}$, BCL-2, cyclin D e Ki-67 pelo método do complexo da estreptavidina-biotina. Resultados - Doze (60\%) pacientes eram homens e a média de idade foi de 67,9 \pm 12,9 anos. Os adenomas foram classificados como do tipo intestinal em 13 (65\%) pacientes e do tipo gástrico em 7 (35\%). Displasia (neoplasia intraepitelial) de baixo grau estava presente em 13 (65\%), displasia de alto grau em 3 (15\%), e adenocarcinoma no pólipo adenomatoso em 4 (20\%) pacientes. Observou-se immunoexpressão do p53 em 6/20 (30\%) adenomas, e em 2/6 (33,3\%) dos tumores sincrônicos. Houve associação entre imunoexpressão do p53 e adenoma/tumor tipo intestinal, $P=0.04$. Não houve associação entre imunoexpressão do p16 $6^{\text {ink4a }}$, Bcl-2, ciclina $\mathrm{D}$ e Ki-67 e as características clinicopatológicas dos adenomas. Conclusão - Imunoistoquímica pode ser utilizada para caracterizar os subtipos de adenoma e talvez indicar o caminho de carcinogênese.

DESCRITORES - Neoplasias do estômago. Adenocarcinoma. Marcadores biológicos de tumor. Regulação bacteriana da expressão gênica. Imunoistoquímica. 


\section{REFERENCES}

1. Abraham SC, Montgomery EA, Singh VK, Yardley JH, Wu TT. Gastric adenomas: intestinal-type and gastric-type adenomas differ in the risk of adenocarcinoma and presence of background mucosal pathology. Am J Surg Pathol. 2002;26:1276-85.

2. Abraham SC, Park SJ, Lee JH, Mugartegui L, Wu TT. Genetic alterations in gastric adenomas of intestinal and foveolar phenotypes. Mod Pathol. 2003;16:786-95.

3. Cattoretti G, Becker MH, Key G, Duchrow M, Schlüter C, Galle J, Gerdes J. Monoclonal antibodies against recombinant parts of the Ki-67 antigen (MIB-1 and MIB-3) detect proliferating cells in microwave-processed formallin-fixed paraffin sections. J Pathol. 1992;168:357-63.

4. Chang MS, Kim HS, Kim CW, Kim YI, Lan Lee B, Kim WH. Epstein-Barr Virus, $\mathrm{p} 53$, protein and microsatellite instability in the adenoma-carcinoma sequence of the stomach. Hum Pathol. 2002;33:415-20.

5. Chaves DM, Iriya K, Maluf F, Tomishige T, Sakai P, Ishioka S. Adenoma gástrico: aspectos endoscópicos, histológicos e considerações gerais. GED Gastroenterol Endosc Dig. 1997;16:119-22.

6. Clarke MR, Safatle-Ribeiro AV, Ribeiro U, Sakai P, Reynolds JC. bcl-2 protein expression in gastric remnant mucosa and gastric cancer 15 or more years after partial gastrectomy. Mod Pathol. 1997;10:1021-7.

7. Feakins RM, Nickols CD, Bidd H, Walton SJ. Abnormal expression of $\mathrm{pRb}$, p16 ${ }^{\text {INK4a }}$ and Cyclin D1 in gastric adenocarcinoma and its lymph node metastases: relationship with pathological features and survival. Hum Pathol. 2003;34:1276-82.

8. Finlay CA, Hinds PW, Levine AJ. The $\mathrm{p} 53$ protooncogene can act as a suppressor of transformation. Cell. 1989;57:1083-93.

9. Igarashi N, Takahashi M, Ohkubo H, Omata K, Lida R, Fujimoto S. Predictive value of $\mathrm{Ki}-67, \mathrm{p} 53$ protein and DNA content in the diagnosis of gastric carcinoma. Cancer. 1999;86:1449-54.

10. Kamiya T, Morishita T, Asakura H, Miura S, Munakata Y, Tsuchiya M. Longterm follow-up study on gastric adenoma and its relation to gastric protruded carcinoma. Cancer. 1982;50:2496-503.

11. Kushima R, Müller W, Stolte M and Borchard F. Differential p53 protein expression in stomach adenomas of gastric and intestinal phenotypes: possible sequences of p53 alteration in stomach carcinogenesis. Virchows Arch. 1996;428:223-7.

12. Lee HK, Lee HS, Yang HK, Kim WH, Lee KU, Choe KJ, Kim JP. Prognostic significance of $\mathrm{Bcl}-2$ and p53 expression in gastric cancer. Int $\mathrm{J}$ Colorectal Dis. 2003; 18:518-25.

13. Lee HS, Lee HK, Kim HS, Yang HK, Kim YII, Kim WH. MUC1, MUC2, MU $\mathrm{C} 5 \mathrm{AC}$, and MUC6 expressions in gastric carcinomas: their roles as prognostic indicators. Cancer. 2001;92:1427-34

14. Levine AJ. p53, the cellular gatekeeper for growth and division. Cell. 1997;88: 323-31.
15. Machado JC, Nogueira AM, Carneiro F, Reis CA, Sobrinho-Simões M. Gastric carcinoma exhibits distinct types of cell differentiation: an immunohistochemical study of trefoil peptides (TFF1 and TFF2) and mucins (MUC1,MUC2,MUC5AC and MUC6). J Pathol. 2000;190:437-43.

16. Nakamura K, Sakaguchi H, Enjoji M. Depressed adenoma of the stomach. Cancer. 1988;62:2197-202.

17. Nigro JM, Baker SJ, Preisinger AC, Jessup JM, Hostetter R, Cleary K, Bigner SH, Davidson N, Baylin S, Davilee P. Mutation in the p53 gene occur in diverse human tumor types. Nature. 1989;342:705-8.

18. Oya M, Yao T, Tsuneyoshi M. Expressions of cell-cycle regulatory gene products in conventional gastric adenomas: possible immunohistochemical markers of malignant transformation. Hum Pathol. 2000;31:279-87.

19. Oya M, Yao T, Nakamura T, Nakanishi K, Tsuneyoshi M. Intestinal phenotypic expression of gastric depressed adenomas and the surrounding mucosa. Gastric Cancer. 2003;6:179-84.

20. Safatle-Ribeiro AV, Ribeiro Jr. U, Reynolds JC, Gama-Rodrigues JJ, Iriya K, Kim R, Bakker A, Swalsky PA, Pinotti HW, Finkelstein SD. Morphologic, histologic, and molecular similarities between adenocarcinomas arising in the gastric stump and in the intact stomach. Cancer. 1996;78:2288-99.

21. Sakurai S, Sano T, Maeshima A, Kashiwabara K, Oyama T, Fukuda T, Nakajima T. Gastric adenoma - carcinoma sequence with special reference to p53 and K-ras gene alterations. Virchows Arch. 1995;427:119-24.

22. Shibata N, Watari J, Fujiya M, Tanno S, Saitoh Y, Kohgo Y. Cell kinetics and genetic instabilities in differentiated type early gastric cancers with different mucin phenotype. Hum Pathol. 2003;4:32-40.

23. Sugai T, Habano W, Uesugi N, Jao UF, Nakamura SI, Abe K, Takagane A, Terashima M. Three independent genetic profiles based on mucin expression in early differentiated-type gastric cancers-a new concept of genetic carcinogenesis of early differentiated-type adenocarcinomas. Mod Pathol. 2004;17:1223-34.

24. Tahara E. Genetic alterations in human gastrointestinal cancers. The application to molecular diagnosis. Cancer. 1995;75:1410-7.

25. Tsujitani S, Furusawa M, Hayashi I. Morphological factors aid in therapeutic decisions concerning gastric adenomas. Hepatogastroenterology. 1992;39:56-8.

26. Tsukashita S, Kushima R, Bamba M, Sugihara H, Hattori T. MUC gene expression and histogenesis of adenocarcinoma of the stomach. Int $\mathrm{J}$ Cancer. 2001;95:166-170

27. Uesugi H, Saegusa M, Takano Y, Okayasu I. Different expression of Bcl-2 protein in gastric adenomas and carcinomas. Pathol Int. 1996;46:274-80.

28. Vieth M, Schneider-Stock R, Röhrich K, May A, Ell C, Markwarth A, Roessner A, Stolte M, Tannapfel A. INK4a-ARF alteration in Barrett's epithelium, intraepithelial neoplasia and Barrett's adenocarcinoma. Virchows Arch. 2004;445:135-41.

29. Zhao GH, Lee TC, Shi, LH, Xia YB, Lu LM, Huang WB, Sun HL, Zhang YS Relationship between inactivation of p16 gene and gastric carcinoma. World J Gastroenterol. 2003;9:905-9. 